PRZEGLĄD NAUK HISTORYCZNYCH 2017, R. XVI, NR 2

http://dx.doi.org/10.18778/1644-857X.16.02.04

Michat Kobierecki

ŁÓDŻ

\title{
Dobra szlacheckie i ich wlaściciele w powiecie orłowskim w drugiej połowie XVIII wieku
}

Streszczenie. Powiat orłowski, należący do najmniejszych pod względem powierzchni w Rzeczypospolitej Obojga Narodów, wchodził w skład województwa łęczyckiego. Miasta, wsie i inne nieruchomości istniejące w tym powiecie należały jedynie do szlachty i Kościoła katolickiego. Współcześni historycy badający własność owych dóbr w XVI i XVII stuleciu ustalili jednoznacznie, że na obszarze owego powiatu nie doszło do kumulacji i utworzenia kilkunastowioskowych bądź jeszcze większych majątków. Z drugiej strony właściciele dóbr szlacheckich nie byli zbyt zamożnymi w kraju, jak również w województwie. Sytuacja nie zmieniła się w następnym stuleciu, co potwierdzaja wyniki badań rejestrami podymnego z 1775 r. i pogłównego z 1790 r., które objęły całe województwo łęczyckie. W tym czasie do najbogatszych należeli wojewoda łęczycki Szymon Dzierzbicki, posiadający miasto Bielawę i osiem wsi, czy wojewoda witebski Józef Sołłohub, właściciel miasta Żychlina oraz sześciu i części wsi. W 1790 r. największy majątek, liczący sześć wsi, należał do generała wojsk rosyjskich Jana Sołłohuba. To potwierdza, że na obszarze powiatu orłowskiego nie było majątków szlacheckich składających się z więcej niż 10 miejscowości. Dominowały majątki niewielkie, składające się z jednej, dwu bądź części wsi, należących w większości do ubogiej szlachty. W niektórych przypadkach wsie miały po dwóch-trzech właścicieli, a zdarzały się przypadki, że nawet 13 . W ciagu 15 lat nie nastapiła zdecydowana zmiana, ponieważ nie dokonał się proces scalania dóbr. Ta grupa właścicieli nie zmniejszyła się, a analiza liczby dymów we wsiach powiatu orłowskiego z 1790 r. wykazała, że spora część orłowskiej szlachty zajmowała się praca na roli i była również zwolniona z płacenia podatków ze względu na zbyt mały majatek.

Słowa kluczowe: polska szlachta w XVIII w., powiat orłowski, własność szlachecka.

\footnotetext{
*E-mail: m.kobierecki@vp.pl.
} 


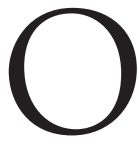

powiecie orłowskim położonym w staropolskim województwie łęczyckim powstało wiele prac. Szczególne w tym zasługi miał Stanisław Marian Zajączkowski, który interesował się osadnictwem, strukturą własności czy podziałami kościelnymi na tym terenie $\mathrm{w}$ epoce średniowiecza ${ }^{1}$. W swoich dogłębnych badaniach brał pod uwage wiele różnych czynników, m.in. granice, położenie geograficzne i środowisko naturalne $z$ uwzględnieniem występujących tam rodzajów gleb oraz opis hydrograficzny czy zalesienie. Wyniki analiz skłoniły go do stwierdzenia, że na obszarze tego powiatu istniały w tamtym okresie dobre warunki do rozwoju gospodarki rolnej. Innym czynnikiem podnoszącym rozwój gospodarczy owego obszaru była, istniejąca pod koniec średniowiecza i na początku epoki nowożytnej, sieć drożna, która zdecydowanie ułatwiała komunikację².

Podział administracyjny dla województwa łęczyckiego wywodził się ze średniowiecza i był niezmienny w epoce nowożytnej. Województwo było podzielone na trzy powiaty, a orłowski, o powierzchni $629,8 \mathrm{~km} \mathrm{kw}{ }^{2}$, był najmniejszy. Pozostałe liczyły 2447,59 - łęczycki i $1300,85 \mathrm{~km} \mathrm{kw}^{2}$ - brzeziński ${ }^{3}$. Kolejny powiat, inowłodzki pojawił się w konstytucjach sejmu z 1726 r., ale w rzeczywistości nie funkcjonował, ponieważ brakuje ksiąg grodzkich, a w księgach brzezińskich pochodzacych $z$ XVIII w. nie ma żadnych informacji na ten temat. Być może wiązało się to $z$ utworzeniem w tym okresie hierar-

1 S.M. Zajaczkow ski, Powiat orłowski do lat siedemdziesiatych XVI wieku. Studia $z$ dziejów osadnictwa struktury własnościowej i stosunków kościelnych, Łódź 1996; i d e m, Uwagi o przeszłości Orłowa do lat siedemdziesiatych XVI wieku, „Rocznik Łódzki” 1996, t. XLIII, s. 53-72; i d e m, Sieć parafialna na obszarze przedrozbiorowego powiatu orłowskiego do końca XVI wieku, Kutno 2001.

${ }^{2}$ I d e m, Powiat orlowski..., s. 14-33.

${ }^{3}$ Stanisław M. Zajączkowski informacje dotyczace wielkości powiatu powtarzał za Tadeuszem Sobczakiem i Leszkiem Kajzerem, którzy opierali się na Adolfie Pawińskim. Jednak według S.M. Zajączkowskiego łączna powierzchnia województwa wyniosła $4376,8 \mathrm{~km}^{2}$, natomiast T. Sobczak podał, że wyniosła $4378,2 \mathrm{~km}^{2}$. Różnica wynikała $z$ posługiwania się różnymi danymi, mniej lub bardziej szczegółowymi. Łaczna powierzchnia $z$ dwoma miejscami po przecinku wynosi $4378,24 \mathrm{~km}^{2}$. Inna wielkość podaje Atlas historyczny..., wyliczajac, że było to $4326 \mathrm{~km}^{2}$. S.M. Zajaczkowski, Powiat orłowski..., s. 7; L. Kajze r, Studia nad świeckim budownictwem obronnym województwa łęczyckiego w XIII-XVII wieku, „Acta Universitatis Lodziensis", Folia Archaeologica 1980, t. I, s. 10; T. Sobczak, Zmiany w stanie posiadania dóbr ziemskich $w$ województwie łęczyckim od XVI do XVIII wieku, „Roczniki Dziejów Społecznych i Gospodarczych” 1955, t. XVII, s. 166; Atlas historyczny Polski, t. V (Województwo sieradzkie i województwo łęczyckie $w$ drugiej połowie XVI wieku), cz. 2, red. H. Rutkowski, Warszawa 1998, s. 49. 
chii urzędów ziemskich dla Inowłodza. Mimo tego termin „powiat inowłodzki" nadal pojawiał się w lustracji dóbr królewskich sporządzonej w $1765 \mathrm{r}$. oraz w instrukcji poselskiej z $1782 \mathrm{r}$. wystawionej przez sejmik łęczycki. Ostatecznie sprawa ta znalazła swój finał w czasie obrad Sejmu Czteroletniego, gdzie wyodrębniono ów powiat jako osobna jednostke administracyjna, ale nie przeprowadzono wydzielenia jego granic. W ten sposób powiat brzeziński pozostał w praktyce w całości aż do drugiego rozbioru Rzeczypospolitej.

W XVIII w. na terenie powiatu orłowskiego nie było własności królewskiej. Wynikało to $z$ działań monarchów w poprzednich stuleciach, którzy obdarowywali dobrami królewskimi duchowieństwo, jak w przypadku kompleksu dóbr zduńskich, czy szlachtę, która otrzymała Żychlin oraz Doliwów. Inną cecha powiatu orłowskiego było posiadanie przez średnią i drobną szlachtę większości majątków. Ich wartość wzrastała w tym czasie przede wszystkim na skutek tworzenia nowych osad. Jednak często ulegały one podziałom wynikającym np. $z$ dziedziczenia ${ }^{4}$. Dotyczyło to majątków wielowioskowych oraz pojedynczych wsi, które były dzielone na części. Natomiast dzięki zawieraniu małżeństw czy nabywaniu powiększały się dobra i dochody. W wielu wypadkach wynikało to $z$ umiejętności i zdolności jednostki. Tego rodzaju zjawiska były szczególnie dobrze widoczne w niewielkim pod względem obszaru powiecie orłowskim, gdzie kumulacja w jednym ręku kilku wsi dawała awans i szybki przeskok w hierarchii lokalnej szlachty. Jednak często po śmierci takiej osoby majątek, wyrastający ponad inne w powiecie, ulegał podziałowi ${ }^{5}$.

Takie wnioski sformułował S.M. Zajączkowski, który w XV-XVI w. wyodrębnił na terenie powiatu orłowskiego siedem kompleksów dóbr należących do bogatej szlachty. Wiadomo, że nie przetrwały one w dłuższym okresie, a część wsi znalazła się w rękach innych właścicieli. Jednak czasami trudno określić, kiedy owe zmiany nastąpiły, ponieważ $\mathrm{w}$ księgach grodzkich właściciele nadal występowali jako wielowioskowi posiadacze, choć faktycznie w ich rękach znajdowała się tylko część wcześniejszego majątku. Stanisław M. Zajączkowski zwrócił również uwagę na to, że najwięcej osad znajdowało się w rękach drobnej szlachty. Różnice w poziomie zamożności nie były duże, a właścicieli jednej bądź dwu wsi można

${ }^{4}$ S.M. Zajaczkowski, Powiat orłowski..., s. 146.

5 Ibidem, s. 147. 
było zaliczyć do grona średniej szlachty, co wydaje się specyficzne dla oceny niezbyt wielkiego obszaru ${ }^{6}$.

Pod tym względem sytuacja nie zmieniła się w XVI stuleciu, co potwierdziły wyniki badań opartych na analizie źródeł o charakterze skarbowym $z$ drugiej połowy tego wieku, przeprowadzonych przez Tadeusza Sobczaka. Według niego w powiecie orłowskim przeważała szlachta posiadająca majątki składające się $z$ niewielkiej liczby wsi. Wyliczył, że w całym województwie łęczyckim $60 \%$ wsi było podzielonych, a największa ich liczba przypadła na powiat orłowski. Warto podkreślić, że podzielone wsie nie były sobie równe i ich części mogły wchodzić w skład różnych dóbr, posiadać innych właścicieli ${ }^{7} . Z$ drugiej strony jedynie $35 \%$ wsi szlacheckich $w$ tym powiecie tworzyło majątki jednowioskowe ${ }^{8}$. Tylko $20 \%$ wsi, najczęściej były one w całości, tworzyło majętności wielowioskowe. W tej grupie były także majątki składające się $z$ dóbr nieleżących na terenie powiatu orłowskiego. Zdarzały się również przypadki majętności nieposiadającej żadnej wsi, lecz jedynie kilka części. Czasami powierzchnia takich majątków, liczona w łanach, była o wiele większa od tych składających się $z$ jednej lub dwu, a nawet $z$ trzech wsi ${ }^{9}$.

Na podstawie zebranych informacji o stanie posiadania szlachty w powiecie orłowskim T. Sobczak wyróżnił trzy grupy. W pierwszej i w trzeciej dokonał dodatkowych podziałów. Do najuboższej zaliczył szlachtę cząstkowa, która w swych rękach posiadała 134 majątki. Tworzyło je 54 i pół wsi. W drugiej znalazło się 37 majętności, w tym siedem wielowioskowych, pozostałe to jednowioskowe. Składały sie one $z 40$ i połowy wsi. W ostatniej grupie 24 wsie przypadły na cztery majatki wielowioskowe ${ }^{10}$. W celu uzupełnienia i potwierdzenia obrazu zamożności szlachetnie urodzonych należy wskazać, że największy odsetek szlachty zaściankowej w województwie łęczyckim zamieszkiwał w powiecie orłowskim. Warte podkreślenia było również zjawisko posiadania majątków mniejszych niż gospodarstwa kmiece, np. w 25 wsiach było 286 zagród szlacheckich, w tym 46

${ }^{6}$ Według S.M. Zajączkowskiego wykazy poboru podatków np. z XVI w. opublikowane przez Adolfa Pawińskiego były dokładniejszym źródłem informacji o właścicielu nieruchomości. Ibidem, s. 161, 162, 218.

7 T. Sobczak, op. cit., s. 168, 169.

8 Ibidem, s. 172.

9 Ibidem, s. 173.

${ }^{10} \mathrm{~W}$ trzeciej grupie, składającej się z czterech majątków, największy liczył 12 wsi, a pozostałe po sześć, trzy i dwa. Ibidem, s. 171. 
jednołanowych. Owa szlachta żyła na północ od rzeki Bzury i dość licznie na pograniczu powiatów łęczyckiego i orłowskiego ${ }^{11}$.

W następnym stuleciu sytuacja pod względem struktury własności znacząco się nie zmieniła. Jednak to, co różniło się od poprzedniego stanu, to to, że w drugiej połowie XVII w. w województwie łęczyckim pojawiła się większa liczba majątków wielowioskowych. W 1661 r. były to dobra należące do Szczawińskich (liczyły one ok. 20 wsi), Korycińskich (11,5 wsi) czy Adama Bełdowskiego, Mateusza Rysińskiego oraz nieżyjącego Rajmunda Bykowskiego (wszystkie miały po dziewięć wsi). $Z$ drugiej strony widoczny był regres osadnictwa, a spora część właścicieli (oblicza się ją na 1185 osób) straciła majątki i zasilała grupę nieposesjonatów, którzy mogli szukać źródeł utrzymania w miastach, np. w Piotrkowie, gdzie odbywały się regularnie trybunały ${ }^{12}$. W latach 1661-1683 nie zaobserwowano również żadnych zmian w powiecie orłowskim. Według podziału na cztery grupy, jaki przeprowadził Wojciech Szczygielski dla potrzeb określenia stanu zamożności szlachty województwa łęczyckiego, wynika, że najwięcej wsi przypadło średniej szlachcie. W przypadku powiatu orłowskiego w $1661 \mathrm{r}$. w rękach tej grupy znalazło się 45,1\% wsi, a w 1683 r. - 55,7\%. W ciagu owych 22 lat zaszły także zmiany w stanie posiadania w pozostałych grupach. Po „potopie” druga grupa posiadającą w swych rękach najwięcej wsi była szlachta zamożna $(28,3 \%)$, następnie drobna $(26,6 \%)$. Dla porównania: w $1683 \mathrm{r}$. $33,3 \%$ wsi posiadali najubożsi właściciele ziemscy, a $11 \%$ bogata szlachta. W obu przypadkach nie było przedstawicieli najbogatszej grupy szlachty. Uzupełnieniem przedstawionych danych były wyliczenia dotyczące liczby majątków. Najwięcej z nich, bo prawie $75 \%$, w obu prezentowanych latach, znajdowało się w rękach najuboższej szlachty, co dobitnie świadczy o poważnym zubożeniu szlachetnie urodzonych mieszkańców tego powiatu. Natomiast w grupie bogatej szlachty było najpierw sześć majątków, a później jedynie dwa. Według W. Szczygielskiego ta zmiana wynikała $z$ kilku przyczyn: powiększania folwarków, zadłużenia dóbr, opustoszenia osad oraz pogarszajacych się warunków życia - i nie było to związane jedynie ze zniszczeniami wojennymi, jakie przyniosła

11 Ibidem, s.174, 175.

${ }^{12}$ W. Szczygielski, Struktura społeczno-własnościowa szlachty łęczyckiej w poczatkach drugiej połowy XVII w., „Acta Universitatis Lodziensis”, „Zeszyty Naukowe Uniwersytetu Łódzkiego", Nauki Humanistyczno-Społeczne, Folia Historica, Seria I, „Feudalizm”, 1979, z. 57, s. 161, 162, 163. 
wojna ze Szwecją w latach 1655-1660. Koncentracja majątków była również zauważalna wśród średniej szlachty, gdzie nastąił wzrost z 22,7\% majątków do 25,4\%. Było to możliwe ze względu na dość liczną liczbę szlachty zagrodowej i wynikające $z$ tego naturalne zjawisko łączenia dóbr przez jednego właściciela ${ }^{13}$.

W XVIII stuleciu istotnym źródłem informacji o stanie zamożności szlachty z powiatu orłowskiego były taryfa podymnego z $1775 \mathrm{r}$. i pogłównego $z 1790 \mathrm{r}$. Były one związane $z$ poborem podatków. Pierwszy $z$ nich po raz pierwszy został uchwalony na sejmie zwyczajnym w 1629 r., gdy szukano pieniędzy na wojnę ze Szwecją. Na poczatku zbierany był nie od dymu, lecz od domu i inne były stawki w miastach oraz wsiach. Spełniał swoją funkcję w XVII w., ale nie był sprawiedliwy, obciążając jedną kwotą bardziej zamożnych, jak i biedniejszych podatników. W kolejnym stuleciu zaniechano go ${ }^{14}$. Drugi $z$ wymienionych podatków to pogłówne, które w XVII w. często nakładano na ludność żydowska, a czasami na przedstawicieli innych nacji, jak Szkotów, Persów, Ormian czy Greków będących kupcami. Po raz pierwszy pogłówne generalne przyjęto w 1590 r., ale go nie wybrano. Natomiast w drugiej połowie XVII w. wrócono do tego pomysłu i najpierw sporadycznie, a później coraz częściej było uchwalane i egzekwowane. Od 1717 r. pogłówne generalne stało się podstawowym źródłem dochodu, obok wpływów $z$ hiberny, potrzebnym do finansowania wojska. Było ono zróżnicowane co do wysokości, zależnie od pozycji stanowej i urzędniczej podatnika. Z upływem czasu zwiększano jego wysokość i coraz większe obciążenia spadały na biedniejsze grupy ludności ${ }^{15}$.

Dopiero zmiany w podatkach poczynione za panowania Stanisława Augusta zmieniły sytuację. Sejm delegacyjny ustanowił podatek podymny 14 lutego 1775 r. i miał on zastąić pogłówne i hibernę oraz "dawne podymne”. To podymne generalne obejmowało wszystkie dobra królewskie, duchowne i prywatne. Ustalono stawki 7 i 5 złp. od dymu, czyli komina we wsiach, płacone

${ }^{13}$ Ibidem, s. 155, 159, 160.

${ }^{14}$ M. Nycz, Geneza reform skarbowych sejmu niemego. Studium $z$ dziejów skarbowo-wojskowych z lat 1697-1717, Poznań 1938, s. 51, 53; A. Filipczak-Kocur, Skarbowość Rzeczypospolitej 1587-1648. Projekty, ustawy, realizacja, Warszawa 2006, s. 53-58.

${ }^{15}$ M. Nycz, op. cit., s. 53-54; M. Drozdowski, Podstawy finansowe działalności państwowej w Polsce 1764-1793. Działalność budżetowa Sejmu Rzeczypospolitej w czasach panowania Stanisława Augusta Poniatowskiego, WarszawaPoznań 1975, s. 34; A. Filipczak-Kocur, op. cit., s. 65-66. 
co roku, co było bardziej sprawiedliwe niż pogłówne w tej samej stawce dla wszystkich. Dochody $z$ tego podatku stały się podstawowym źródłem zasilenia budżetu państwowego, przynosząc 5 mln złp. w Koronie ${ }^{16}$. Kolejną zmianę przyniósł Sejm Wielki, na którym uchwalono podatek 10 gr od dochodu $z$ dóbr szlacheckich i wtedy doszło do opracowania taryfy pogłównego dla województwa łęczyckiego w $1790 \mathrm{r}$.

Oba zestawienia podatkowe ${ }^{17}$ nie różniły się między sobą, ponieważ oprócz informacji o nazwie miasta lub wsi oraz ich właścicielu bąź właścicielach podstawowa wartościa, jaka podawano, była liczba dymów. Jednak w taryfie z 1775 r. wymieniano ogólną liczbę dymów w danej miejscowości, podając jednocześnie, ile należało do szlachty, duchowieństwa czy kmieci. Sporządzano je dla całego województwa, które zostało podzielone na powiaty, a te na parafie, w których umieszczono alfabetyczny spis opisanych miejscowości.

$\mathrm{Na}$ podstawie informacji $\mathrm{z}$ owych taryf można przedstawić liczbę miast $\mathrm{i}$ wsi istniejacych $\mathrm{w}$ powiecie orłowskim. Wiadomo, że w XVI w., według danych przytoczonych przez T. Sobczaka, istniało 159 wsi i pięć miast należących do szlachty i Kościoła ${ }^{18}$. Bielawę, Oporów, Orłów, Sobotę i Żychlin jako miasta wymienił także Atlas historyczny Polski, a oprócz tego 172 wsie. $Z$ tej liczby $90 \%$ to były wsie szlacheckie $^{19}$. Tak poważną różnicę między danymi dotyczącymi liczby wsi należy tłumaczyć metodą zastosowana przez badaczy, np. traktowania części jako odrębnej jednostki osadniczej. W drugiej połowie XVII w., ok. roku 1661, 137 wsi należało do szlachty,

16 Volumina legum, t. VIII, s. 88; T. Korzon, Wewnętrzne dzieje Polski za Stanisława Augusta (1764-1794), t. III, Kraków-Warszawa 1897, s. 158-159, 160; M. Drozdowski, op. cit., s. 74, 78 .

17 Informacje o obu taryfach podatkowych dotrwały do naszych czasów i sa przechowywane w Archiwum Głównym Akt Dawnych w Warszawie. Taryfa podymnego z 1775 r. znajduje się w księgach grodzkich łęczyckich, varia nr 7 „Taryfa podymnego i czopowego 1775 r.". Natomiast taryfa pogłównego z 1790 r. w księgach grodzkich łęczyckich, varia nr 11 „Taryfy podatku podymnego z dóbr dziedzicznych, duchownych i królewskich województwa łęczyckiego". T. Wierzbowski, Akty ziemskie i grodzkie XIV-XVIII w. województw wielkopolskich, [w:] Monumenta iuris, t. VI, Warszawa 1917, s. 121; H. W aj s, Materiały skarbowe w aktach ziemskich i grodzkich $w$ AGAD (na przykładzie akt sieradzkich $i$ łęczyckich), „Miscellanea Historico-Archivistica" 1999, t. X, s. 76-115.

18 T. Sobczak, op. cit., s. $178,179$.

19 W całym województwie łęczyckim 82,5\% wsi należało do właścicieli szlacheckich. Ten stan był również właścicielem prawie $65 \%$ powierzchni całego województwa. Atlas historyczny Polski, t. V, tab. 8, s. 63, 71. 
natomiast na podstawie rejestru podatkowego z $1683 \mathrm{r}$. $-126^{20}$. W przypadku XVIII w., na podstawie taryfy podymnego z 1775 r., wiadomo o istnieniu 165 osad, w tym trzech miast (Bielawy, Sobota i Żychlin), Oporów i Orłów zaś ówcześni komisarze uznali za wsie. Natomiast pod względem rodzaju własności 15 wsi należało do Kościoła, a 147 pozostawało w rękach szlachty. W tej grupie było 17 pustek, ale tylko o siedmiu wiadomo, kto był ich właścicielem, a w jednym przypadku dwóch szlachciców posiadało opustoszałą wieś ${ }^{21}$. Ponadto czterech miało inne dobra. Natomiast Stanisław Kożuchowski, posiadajacy pustkę Ostoja ${ }^{22}$, oraz Feliks Zawisza $z$ Zakrzewem ${ }^{23}$, obie leżace w parafii Sobota ${ }^{24}$, nie posiadali innych wsi w tym powiecie. Oddzielnym przykładem była pustka Przykuty ${ }^{25}$, należąca do rodziny Przedpełskich. Została ona oznaczona jako niezamieszkała, ale posiadająca dym chłopski, od którego należało uiścić podatek.

W taryfie pogłównego sporządzonej w 1790 r. wymieniono 162 osady. To mniej niż 15 lat wcześniej, co wynikało $z$ pominięcia 13 pustek, jakie wtedy uwzględniono, ale zwiększyła się własność kościelna do 16 wsi przez uwzględnienie, nieobecnego wcześniej, Bakowa Dolnego. Natomiast 143 wsie i miasta Bielawa, Sobota oraz Żychlin należały do szlachty. Ponadto pojawiły się nowe miejscowości, jak Marcinów w parafii Strzegocin, założony jako osada olenderska, czy Wola Prosperowa w parafii oporowskiej. Uwzględniono również pustki z 1775 r., jak Dobiesławice ${ }^{26}$ i Lisie Jamy ${ }^{27}$,

20 W. Szczygielski, op. cit., s. 155, 158.

${ }^{21}$ Chodzi o Łazino Zdzarowskie (obecnie Łazinek), pustkę należąca do Franciszka Walewskiego i nieznanego z imienia Wojszyckiego, która pomijam w obliczeniach dotyczących majątków i właścicieli, ponieważ obaj posiadali inne dobra. Atlas historyczny Polski, t. V, s. 119.

${ }^{22}$ Według Atlasu historycznego... w XVI w. pustka Ostoja (obecnie Emilianów) leżała na terenie parafii Bakowo. Natomiast w taryfie podymnego z $1775 \mathrm{r}$. wymieniono ją w parafii Sobota. Prawdopodobnie chodzi o tę samą osadę, leżacca na pograniczu obu parafii. Ibidem, s. 123.

${ }^{23}$ Podane w tym artykule nazwy miejscowości sa współczesne. Jedynie w przypadkach, gdy nie dotrwały do naszych czasów, zostały podane w oryginalnym zapisie. Wszystkie nazwy zostały zweryfikowane z Atlasem historycznym Polski, t. V.

${ }^{24} \mathrm{~W}$ taryfie był wymieniony inny Stanisław Kożuchowski, podczaszy orłowski, dysponujący trzema wsiami. Nie można jednak potwierdzić, że chodzi o tę sama osobę, ponieważ nie było żadnych odnośników w tej sprawie. Podobna sytuacja występowała w przypadku Feliksa Zawiszy, gdzie można wymienić żyjącego łowczyca łęczyckiego Feliksa Zawiszę.

${ }^{25}$ Atlas historyczny... nie podaje współczesnej nazwy tej pustki.

${ }^{26}$ Współcześnie nie istnieje. Atlas historyczny Polski, t. V, s. 111.

27 Współcześnie nie istnieje. Ibidem, s. 119. 
leżące w parafii Łęki Kościelne, czy Górki ${ }^{28}$ w parafii Ciechosłanice. Umieszczono je w tej taryfie, ponieważ posiadały dym lub miano $z$ nich płacić podatek dziesiątego grosza.

Informacje $z$ obu taryf pozwoliły na ocenę dotyczaca wielkości majątków, statusu materialnego szlachty, stanu sieci osadniczej czy wielkości osad. W przypadku tej ostatniej wartości wiadomo, że w 1775 r. do wsi liczących najwięcej dymów w powiecie należały: Łęki Kościelne (mające 47, w rękach Leźnickich), Oporów (42, którego właścicielem był wojewoda witebski Józef Sołłohub), Orłów (32, chorąży łęczycki Jan Brochocki), Dobrzelin (27, stolnik gostyniński Jan Bartoszewski) i Skrzeszewy (podczaszy gostyniński Mikorski). Po 15 latach kolejność trzech największych nie zmieniła się: Łęki Kościelne (39 dymów, właścicielem był Tomasz Guzowski), Oporów (36, generał wojsk rosyjskich Jan Sołłohub) oraz Orłów (32, szambelan królewski Antoni Brochocki). Następny był Śleszyn Wielki (29, stolnik bracławski Bagniewski) i Dobrzelin (chorąży gostyniński Edmund Bratoszewski). W porównaniu ze spisem z 1775 r. widać spadek liczby dymów w tych wsiach, co było zauważalne również w pozostałych miejscowościach.

Kolejną kwestia była wielkość majątków szlacheckich w powiecie orłowskim. Wiadomo, że składały się na nie poszczególne wsie lub ich części. $Z$ drugiej strony oba źródła o charakterze skarbowym nie wspominaja, czy dany właściciel posiadał jeszcze dobra w innych powiatach. Dlatego terminy „majętność” czy „majątek” używane w tej pracy odnosza się jedynie do nieruchomości skupionych w rękach jednego właściciela i leżących na terytorium powiatu orłowskiego. $Z$ przedstawionych ustaleń wynikało, że nie było tutaj majątków magnackich. Potwierdziło się to również w drugiej połowie XVIII w. W 1775 r. właścicielem największej majętności był wojewoda łęczycki Szymon Dzierzbicki. Tworzyły ją miasto Bielawa i wsie: Bielawska Wieś, Brzozów, Leżajna, Mroga, Orenice, Oreniczki, Piaski i Piekary, czyli dziewięć osad mających razem 175 dymów. Należy podkreślić, że był to cały majątek wojewody, który mieścił się w obrębie jednego powiatu. Kolejna majętność, będąca w rękach wojewody J. Sołłohuba, składała się z miasta Żychlina i wsi: Budzyń, Dobrzewy, Oporów, Oporówek, Woli Owsianej, Pasieki oraz części Jastrzębia. Łącznie było to siedem osad i część, czyli 186 dymów. W tym przypadku wojewoda dysponował jeszcze dobra-

${ }^{28}$ Obecnie to część wsi o nazwie Górki Pęcławskie. Ibidem, s. 113. 
mi poza granicami województwa łęczyckiego ${ }^{29}$. Trzecią na liście była majętność Antoniego Kossowskiego, właściciela pięciu wsi: Kręcieszek, Madejów ${ }^{30}$, Szewcy Owsianych, Tarnowa i Wojszyc, która leżała na terenie jednej parafii i liczyła 51 dymów. Następnie istniała grupa majątków licząca po cztery wsie należące do: Jana Krosnowskiego (Kaszewy Dworne, Kaszewy Kościelne, Kaszewy Tarnowskie, Konary) - 39 dymów, kasztelana sochaczewskiego Adama Lasockiego (Drogusza, Gosławice, Wola Gosławska, Oszkowice) - 68, Antoniego Podkańskiego (Ciechosławice, Orątki, Pęcławice, Rogaszyn) - 41, Feliksa Stępowskiego (Golędzkie - pustka, Jaworzyna, Odolin, Odolinek) - 16 oraz Ignacego Wilkszyckiego (Płoszczonów ${ }^{31}$, Psary, Skubiki, Waliszew) - 56.

Zestawienie to wyglądało inaczej, gdy głównym kryterium była liczba dymów. Najwięcej miał ich w swoim majątku wojewoda witebski, następnie wojewoda łęczycki. W gronie posiadaczy pięciu lub czterech wsi najlepszym wynikiem mógł się wykazać A. Lasocki, a najgorszym F. Stępowski, który odstawał od pozostałych. Wśród właścicieli trzech lub dwóch wsi można znaleźć majątki mające po 50 dymów, np. Błociszewskiego (Konarzew, Witów i część Jasionnej) - 53, łowczego łęczyckiego W. Zawiszy (miasto Sobota i Sobocka Wieś) - 51, Stanisława Bagniewskiego (Sołek, Śleszyn Wielki, Śleszynek ${ }^{32}$ i część Grzybowa ${ }^{33}$ ) - 50, chorążego łęczyckiego J. Brochockiego (Mosiębrza, Orłów i część Stradzewa) - 49. Ponadto nieznany z imienia Leźnicki, właściciel jedynie wsi Łęki Kościelne, miał w swych rękach 47 dymów.

W 1790 r. najwięcej wsi posiadał generał J. Sołłohub: Dobrzewy, Jastrzębia, Kurów, Świechów, Oporów i Oporówek, w których

${ }^{29}$ Por. P.P. Romaniuk, Sołłohub (Ursyn Dowojna Sołłohub) Józef Antoni h. Prawdzic (1709-1781), kasztelan żmudzki i witebski, wojewoda witebski, [w:] Polski słownik biograficzny, t. XL, Warszawa-Kraków 2000-2001, s. 319-323; id e m, Sołłohub (Ursyn Dowojna Sołłohub) Jan Michał h. Prawdzic (1747-1812?), starosta sannicki, generał $w$ służbie rosyjskiej, [w:] ibidem, s. 315-318; H. Że r ek-Kleszcz, Majętność oporowska i Sołłohubowie w XVIII wieku, [w:] Oporów. Stan badań. Materiały $z$ sesji naukowej zorganizowanej $z$ okazji 50 rocznicy Muzeum w Oporowie 22 listopada 1999 roku, Oporów 2000, s. 135-148.

30 Obecnie jest to część wsi Wojszyce. Atlas historyczny Polski, t. V, s. 120.

${ }^{31}$ Obecnie miejscowość nie istnieje. Ibidem, s. 124.

32 Obecnie miejscowość nie istnieje. Ibidem, s. 130.

${ }^{33} \mathrm{~W}$ Atlasie historycznym... nie wymienia się miejscowości Grzybów, leżącej w parafii Żychlin, jak podaja oba rejestry podymnego. W tym opracowaniu pada nazwa wsi Grzybowo, która była położona w parafii Śleszyno-Sołek i współcześnie nosi nazwę Grzybów Hornowski. Ibidem, s. 113. 
było 95 dymów. Po nim była wojewodzina Dzierzbicka posiadająca w ramach dożywocia pięć wsi (Borówek, Leżajna, Piaski, Piekary, Seligi) i dwie części (w Orenicach i Oryniczkach) - łącznie 85 dymów - oraz Antoni Kossowski z pięcioma wsiami (Kręcieszki, Madeje, Szewce Owsiane, Tarnów, Wojszyce) i częścią (w Szewcach Nadolnych), mającymi tylko 39 dymów. Właścicielami majątków pięciowioskowych byli generał wojsk koronnych Tadeusz Błociszewski (Boczki Domaradzkie, Boczki Zarzeczne, Chlebowice, Konarzew, Witów to łącznie 31 dymów) i kasztelanic rogoziński Józef Molski (Ciechosławice, Oratki, Pęcławice, Rogaszyn i pustka Górki, która płaciła podatek, łącznie 48 dymów). Do grona posiadaczy czterech wsi wchodzili cześnikowa orłowska Marianna Wilkszycka i szambelan królewski A. Brochocki. Oboje posiadali po jednej części $\mathrm{w}$ innych wsiach $^{34}$. Każde $z$ nich miało w swych dobrach więcej dymów niż ci, którzy dysponowali pięcioma wsiami, nawet $z$ częściami. Do grona posiadaczy majątków czterowioskowych należeli: stolnik inowłodzki Jan Krosnowski, szambelan królewski Karol Skarbek oraz kasztelanic owrucki Melchior Trzeciak ${ }^{35}$. Z tej trójki w dobrach K. Skarbka znalazło się 88 dymów, czyli więcej niż w dobrach Dzierzbickiej, co wynikało $z$ posiadania w swych rękach miasta Bielawy, które wtedy liczyło 67 dymów, w tym jeden należał do kościoła parafialnego. Podobna sytuacja była w przypadku kasztelana gdańskiego Tomasza Tadeusza Pruszaka właściciela trzech wsi i 82 dymów. Tutaj również bycie właścicielem miasta Żychlina, liczącego 68 dymów ( $z$ czego 54 wchodziło w skład majątku kasztelana ${ }^{36}$ ), podnosiło dochody i prestiż. Poza tym było pięciu właścicieli trzech lub trzech i części wsi, z których stolnik bracławski, niejaki Bagniewski oraz starosta wyszogrodzki Cyprian Nakwaski mieli po 60 dymów. Jedenastu właścicieli miało dwie lub dwie i części bądź

${ }^{34}$ Marianna Wilkszycka posiadała dzięki dożywociu Płoszczonów, Psary, Skubiki, Waliszew oraz część w Mięsośni. Łącznie w jej majątku było 58 dymów. Szambelan królewski A. Brochocki, właściciel Mirosławic, Mosiębrzy, Orłowa, Tomczyc i części w Garbowie, miał 72 dymy. Ibidem, s. 112, 121, 131.

35 Jan Krosnowski posiadał w swych rękach wsie Konary, Krzyżanów, osadę olenderską Marcinów i pustkę Lisie Jamy, która miała jeden dym - łącznie 36 dymów. Do K. Skarbka należały miasto Bielawa, Bielawska Wieś, Brzozów i Mroga. Natomiast M. Trzeciak posiadał Białą, Kruki, Szczyt oraz Zarębów - łącznie 29 dymów. Ibidem, s. 106, 113, 116, 118, 134, 136.

${ }_{36}$ Tomasz Tadeusz Pruszak był właścicielem Budzynia, Pasieki i Żychlina. W tym mieście obok 31 dymów mieszczan katolickich było 23 żydowskich i 14 należących do parafii. 
część wsi, w tym m.in. podstoli łęczycki Wincenty Bardziński, do którego należała Sobota z 38 dymami, a jego cały majątek liczył o 10 więcej ${ }^{37}$. Była to największa liczba dymów i przewyższała tę, którą dysponował sędzia ziemski łęczycki Paweł Mikorski, właściciel dwóch wsi i dwóch części ${ }^{38}$. W tej grupie znalazł się także Antoni Grabski, właściciel dziewięciu dymów, jak i Bartłomiej Przysiecki - mający ich 12. Pozostali posiadali od 19 do 30 dymów. Trzydziestu właścicieli miało wieś, w tym dwu dodatkowo jakąś część. W tej grupie najwięcej dymów, 36, posiadał Tomasz Guzowski, właściciel największej wsi Łęki Kościelne. Poza tym w grupie tej znaleźli się pułkownik wojsk koronnych Antoni Głębocki, właściciel Plecki Dąbrowy i wdowa Trzcińska mająca Popówek. W każdej z nich było po 23 dymy $^{39}$. Było także ośmiu właścicieli mających jedną wieś, gdzie było od trzech do sześciu dymów ${ }^{40}$.

W 1775 r. wymieniono 142 właścicieli i posesorów, majacych w swych rękach majątki wielowioskowe, jak i te składajace się $z$ części wsi w powiecie orłowskim. W tym gronie znalazło się sześć kobiet, osiem małżeństw i cztery przypadki, gdzie wymieniono sukcesorów po właścicielu. W drugiej taryfie również wymieniono 142 posiadaczy dóbr. Do tego należy dodać pijarów łowickich, posesorów czterech osad, i paulinów $z$ Oporowa, mających w swych rękach wieś. Obok właścicieli i pięciu posesorów, w tym dwóch dzierżawców, znalazło się dwóch mężczyzn posiadajacych dożywotnie prawo do nieruchomości. W dziewięciu przypadkach użytkownikami wsi były kobiety, w tym dwie mające dożywocie. Poza tym wystąpiło dwu sukcesorów oraz trzy małżeństwa.

Przedstawione informacje dotyczące wielkości majątków szlachty $z$ powiatu orłowskiego $\mathrm{w}$ drugiej połowie XVIII w. daja możliwość dokładniejszej oceny ich dochodów i wartości. W tym przypadku kryterium „wsi”, odnoszące się do oceny wielkości majątku i używa-

${ }^{37} \mathrm{~W}$ Sobocie tylko jeden dym należał do parafii. Natomiast 26 było w rękach mieszczan katolickich, a 11 żydowskich.

${ }^{38}$ Paweł Mikorski dysponował majątkiem składajacym się z 42 dymów.

39 W Plecce Dąmbrowej poza tym był jeden dym, który należał do parafii.

40 Po trzy dymy liczyły wsie Goliszew, Buszkówek, Ziewaniczki należące do Wojciecha Kalińskiego, Andrzeja Stęmpowskiego i Julianny Ziemięckiej posesorki. Michał Elzanowski był właścicielem wsi Rybie $z$ czterema dymami. Po pięć dymów miały Drzewoszki Małe, Galice (obecnie ta miejscowość nie istnieje), Buszków, których właścicielami byli niejaki Dęmbowski, Wincenty Domaradzki oraz komornik graniczny łęczycki Jan Rakowiecki. Natomiast wieś Guminy Łętki z sześcioma dymami posiadali Skarżyńscy. Tej ostatniej miejscowości brakuje w Atlasie historycznym... Ibidem, t. V, s. 108, 111, 112, 127, 137. 
ne w literaturze przedmiotu jako uniwersalny czynnik porównywania majątków szlacheckich, zostało urealnione. Jak wiadomo, wieś wsi nie była równa, co najlepiej potwierdziły informacje $z$ obu taryf. Posiadanie danych dotyczacych liczby dymów niewątpliwie uzupełnia obraz wykreowany jedynie na podstawie znajomości liczby wsi. Tym bardziej gdy wieś była dzielona między kilku właścicieli. W przypadku powiatu orłowskiego analiza taryfy z 1775 r. jednoznacznie wskazuje, że na tym obszarze dominowały majątki składające się z jednej części. Tak było w 83 przypadkach. Kolejne trzy majętności miały po dwie części. Natomiast w skład jednego $z$ grupy majątków jednowioskowych, należącego do Franciszka Święstosławskiego, wchodziły dodatkowo dwie części. Było jeszcze pięć innych majątków, które miały tylko jedną część. W dwóch przypadkach majątków dwuwioskowych wiadomo, że posiadały jeszcze po części wsi. Dotyczyło to majętności nieznanego $z$ imienia Błociszewskiego i chorążego łęczyckiego J. Brochockiego. W gronie trzywioskowych tylko ten należący do Stanisława Bagniewskiego miał jeszcze część. Piętnaście lat później było 85 majętności składających się z jednej lub dwu części wsi, co stanowiło 59,86\% wszystkich.

$\mathrm{Na}$ podstawie wyliczeń umieszczonych w tabeli 1 widać, że w ponad $80 \%$ majątki składały się z części lub pojedynczych wsi. Pozostałe liczyły łacznie od ok. $17 \%$ w 1775 r. do ok. $19 \%$ w 1790 r. Wyniki przedstawione $\mathrm{w}$ tabeli pozwoliły się odnieść do prezentowanych wcześniej prac T. Sobczaka i W. Szczygielskiego. Pierwszy $z$ nich dzieli szlachtę na trzy grupy: cząstkowa, jednowioskowa i wielowioskowa ${ }^{41}$. Podział ten niewattpliwie oddaje sytuację szlachty w województwie łęczyckim, jak i w powiecie orłowskim. Jednak w przypadku drugiej połowy XVIII w. różnice między dwiema pierwszymi grupami były niewielkie i to do nich należała zdecydowana większość właścicieli. Według kryteriów przyjętych przez drugiego $z$ autorów, na podstawie danych $z$ lat 1775, 1790, do grona szlachty drobnej zaliczyć można ok. 60\% właścicieli majątków. Do średniej szlachty należało ok. 36\% majętności, a do bogatej - 2-3\%. Najzamożniejszej grupy w powiecie orłowskim nie było. Natomiast, porównując rezultaty badań W. Szczygielskiego, które odnosiły się do lat 1661, 1683, widać redukcję majątków najmniejszych o prawie 15 p.p. i wzrost majętności należących do średniej szlachty,

${ }^{41}$ Tadeusz Sobczak przyjął, że do grupy jednowioskowej zaliczył posiadaczy jednej do dwu niepełnych wsi. Wielowioskowi posiadacze to ci majacy ponad dwie wsie. T. Sobczak, op. cit., s. 168. 
o mniej więcej taką samą wartość. Wśród bogatej szlachty nie było żadnej poważnej zmiany i wzrost o ponad 1 p.p. na przestrzeni ponad stu lat nie może stanowić argumentu za stwierdzeniem o konsolidacji majątków w ich rękach. Taki proces niewątpliwie następował, ale odnosił się on do średniej szlachty.

Liczba wsi w majątkach szlachty w powiecie orłowskim w drugiej połowie XVIII wieku

\begin{tabular}{|c|c|c|c|c|c|}
\hline Lp. & $\begin{array}{c}\text { Liczba wsi } \\
\text { w majątku }\end{array}$ & $\begin{array}{c}\text { Liczba mająt- } \\
\text { ków w 1775 r. }\end{array}$ & $\%$ & $\begin{array}{c}\text { Liczba mają- } \\
\text { ków w 1790 r. }\end{array}$ & $\%$ \\
\hline 1 & $\begin{array}{l}\text { część }- \text { dwie } \\
\text { części }\end{array}$ & 86 & 61,43 & 85 & 59,86 \\
\hline 2 & $1-1+$ części & 30 & 21,43 & 30 & 21,13 \\
\hline 3 & $2-2+$ części & 11 & 7,86 & 11 & 7,75 \\
\hline 4 & $3-3+$ części & 5 & 3,57 & 6 & 4,22 \\
\hline 5 & $4-4+$ części & 5 & 3,57 & 5 & 3,52 \\
\hline 6 & 5 i więcej & 3 & 2,14 & 5 & 3,52 \\
\hline \multicolumn{2}{|c|}{ Łącznie } & 140 & 100 & 142 & 100 \\
\hline
\end{tabular}

Źródło: badania własne.

Ustalenia te potwierdziła analiza liczby dymów. W 1775 r. wymieniono 39 majatków dysponujących jednym dymem. W rzeczywistości ich właścicielami była szlachta, która sama pracowała na roli. Według podziałów przyjętych przy spisie taryfy pięciu $z$ nich miało dym chłopski (co stanowiło 3,57\% majątków), a pozostałych 34 dworskie $(24,29 \%)$. Trudno powiedzieć, czy wielu spośród tej szlachty posiadało inne dobra leżące poza powiatem orłowskim. Można przypuszczać, że w większości przypadków tak nie było. Ponadto dwóch właścicieli posiadało po dymie w dwu różnych częściach (nieznani $z$ imienia Kamiński i Świecki), a sześciu innych miało po części wsi $z$ dwoma dymami. $Z$ drugiej strony zdarzało się, że wieś miała po dwa dymy, jak Leżajna (w parafii Oszkowice) czy 
Żbiwiec (w parafii Bedlno). Pierwsza należała do wojewody łęczyckiego S. Dzierzbickiego, a druga do chorążego inowłodzkiego Jana Stokowskiego.

W 1790 r. istniało 50 majątków składających się $z$ jednego dymu, co stanowiło ponad $1 / 3$, tj. 35,21\% całości. $Z$ tej liczby 41 , co stanowiło $28,87 \%$ wszystkich majątków, zostało zwolnionych $z$ płacenia podatku $z$ powodu braku odpowiedniego dochodu. Tak samo postąpiono w przypadku majątku składającego się $z$ obu jednodymowych części, a w dwu innych zwolniono jedną ${ }^{42}$. Podatku miały nie płacić kolejne trzy z 13 majętności dwudymowych, które składały się $z$ dwu części. Zdarzały się również majątki cząstkowe, liczące od trzech do sześciu dymów ${ }^{43}$. Łącznie na 85 majętności cząstkowych, liczących od jednego do pięciu dymów, 55\% nie płaciło podatku, co stanowiło więcej niż w całym województwie łęczyckim, gdzie nie robiło tego $48,6 \%{ }^{44}$.

Tabela 2

Liczba dymów w majatkach szlacheckich w drugiej połowie XVIII wieku

\begin{tabular}{|c|c|c|c|c|c|}
\hline \multirow{2}{*}{ Lp. } & \multirow{2}{*}{ Dymy } & \multicolumn{2}{|c|}{1775} & \multicolumn{2}{|c|}{1790} \\
\hline & & Majątki & $\%$ & Majątki & $\%$ \\
\hline 1 & 1 & 39 & 27,86 & 50 & 35,21 \\
\hline 2 & 2 & 20 & 14,28 & 14 & 9,86 \\
\hline 3 & 3 & 8 & 5,71 & 8 & 5,63 \\
\hline 4 & 4 & 6 & 4,29 & 5 & 3,52 \\
\hline 5 & 5 & 2 & 1,43 & 8 & 5,63 \\
\hline 6 & $\begin{array}{c}\text { od } 6 \\
\text { do } 10\end{array}$ & 26 & 18,57 & 12 & 8,46 \\
\hline 7 & $\begin{array}{l}\text { od } 11 \\
\text { do } 20\end{array}$ & 16 & 11,43 & 17 & 11,97 \\
\hline 8 & $\begin{array}{l}\text { od } 21 \\
\text { do } 30\end{array}$ & 8 & 5,71 & 12 & 8,46 \\
\hline
\end{tabular}

${ }^{42}$ Łącznie było siedem majątków składajacych się $z$ dwu jednodymowych części.

${ }^{43}$ Majątków mających trzy dymy było cztery. Kolejne dwa miały cztery dymy, a cztery liczyły po pięć dymów i tyle samo po sześć.

${ }^{44}$ T. Sobczak, op. cit., s. 181. 
Tabela 2 cd.

\begin{tabular}{|c|c|c|c|c|c|}
\hline \multirow{2}{*}{ Lp. } & \multirow{2}{*}{ Dymy } & \multicolumn{2}{|c|}{1775} & \multicolumn{2}{c|}{1790} \\
\cline { 3 - 6 } & Majątki & $\%$ & Majątki & $\%$ \\
\hline 9 & $\begin{array}{c}\text { od } 31 \\
\text { do } 50\end{array}$ & 9 & 6,43 & 8 & 5,63 \\
\hline 10 & $\begin{array}{c}\text { powyżej } \\
50\end{array}$ & 6 & 4,29 & 8 & 5,63 \\
\hline \multicolumn{2}{|c|}{ Lącznie } & 140 & 100 & 142 & 100 \\
\hline
\end{tabular}

Źródło: badania własne.

Szlachta posiadająca swoje majątki w powiecie orłowskim należała w większości do niezbyt zamożnej grupy właścicieli ziemskich. Nie wiadomo, w jak poważnym stopniu oddziaływało to na podział albo scalanie wsi, jednak takie procesy miały miejsce. W $1775 \mathrm{r}$. istniało 30 podzielonych wsi, co stanowiło 20,41\% wszystkich, a w 1790 r. było ich 24, co dało 16,78\%. Wyniki najlepiej obrazuje tabela 3. Widoczny spadek to efekt scalania w przypadku 14 wsi. Proces ten odnosił się nie tylko do połączenia wszystkich części w całość, co stało się w dziewięciu przypadkach, lecz także do łączenia dwu, trzech części, gdy miejscowość nadal była podzielona. Patrząc na to $z$ drugiej strony, owa konsolidacja następowała w ciagu dość krótkiego okresu, czyli w ciagu 15 lat. Sukcesem np. zakończyły się starania Wincentego Domaradzkiego, który przejął od czterech różnych właścicieli części wsi Galice, licząca pięć dymów. Najczęściej łączono dwie części, a jedynie Tomasz Magnuski, posiadający jedna w Młogoszynie, przeją dwie pozostałe od krewnych. W tak krótkim czasie proces scalania nie był zbyt imponujacy i nadal w ośmiu wsiach nic się pod tym względem nie zmieniło. Negatywnym zjawiskiem było to, że w kolejnych 11 przypadkach następowały podziały. W 1775 r. pod względem liczby właścicieli dominowały Grzybów z dziewięcioma, Groszki z ośmioma i Szewce Nagórne $z$ siedmioma posesjonatami. Piętnaście lat później zmieniła się kolejność: Groszki miały 13 właścicieli, Grzybów 11, a po dziewięć Szewce Nagórne i Kamienna. Ta ostatnia miejscowość w krótkim okresie została podzielona $z$ czterech na dziewięć części. Tylko w jednym przypadku w obu taryfach pojawiło się to samo nazwisko i być może po śmierci pozostałych właścicieli pojawili się spadkobiercy. Tak było niewatpliwie w przypadku wsi Groszki, gdzie podziały majątkowe wśród przedstawicieli rodzin 
Groszkowskich i Iskrzyckich przyczyniły się do liczby właścicieli. W pozostałych dziewięciu przypadkach najczęściej wydzielano jeszcze dwie nowe części, a w trzech pozostałych - jedną.

Tabela 3

Liczba części we wsiach szlacheckich powiatu orłowskiego w drugiej połowie XVIII wieku

\begin{tabular}{|c|c|c|c|c|}
\hline $\begin{array}{l}\text { Części } \\
\text { wsi }\end{array}$ & $\begin{array}{l}\text { Liczba wsi } \\
\text { w } 1775 \text { r. }\end{array}$ & $\begin{array}{c}\% \text { wsi } \\
\text { w } 1775 \text { r. }\end{array}$ & $\begin{array}{l}\text { Liczba wsi } \\
\text { w } 1790 \text { r. }\end{array}$ & $\begin{array}{c}\% \text { wsi } \\
\text { w } 1790 \text { r. }\end{array}$ \\
\hline 2 & 13 & 8,84 & 8 & 5,59 \\
\hline 3 & 6 & 4,08 & 7 & 4,89 \\
\hline 4 & 5 & 3,40 & 2 & 1,40 \\
\hline 5 & 2 & 1,36 & 2 & 1,40 \\
\hline 6 & 1 & 0,68 & 0 & - \\
\hline 7 & 1 & 0,68 & 1 & 0,7 \\
\hline 8 & 1 & 0,68 & 0 & - \\
\hline 9 & 1 & 0,68 & 1 & 0,7 \\
\hline 10 & 0 & - & 1 & 0,7 \\
\hline 11 & 0 & - & 1 & 0,7 \\
\hline 13 & 0 & - & 1 & 0,7 \\
\hline Łącznie & 30 & 20,40 & 24 & 16,78 \\
\hline
\end{tabular}

Źródło: badania własne

Na podstawie analizy taryf $z$ lat 1775 i 1790 wynika, że dobra szlacheckie w powiecie orłowskim należały do niezbyt zamożnej szlachty i pewna jej część pracowała na roli. Krótka przestrzeń czasowa, 15 lat, nie daje możliwości zauważenia procesu, który by zmienił sytuację właścicieli dóbr szlacheckich w powiecie orłowskim w drugiej połowie XVIII w. Stan wyjściowy, czyli liczba miast i wsi dla obu rejestrów podatkowych po wyłączeniu pustych osad, wydaje się niezmienny. Inaczej wygląda sprawa dymów w mająt- 
kach szlacheckich. Na przestrzeni tego okresu można zauważyć spadek liczby dymów w największych wsiach. $Z$ tego też powodu zdarzały się sytuacje, w których właściciel większej ich liczby miał mniej wsi w swych rękach niż ten, który posiadał więcej od niego osad, co potwierdza niedoskonałość uniwersalnego kryterium, jakim była liczba wsi. Pewna ułomnością owych taryf było to, że służyły one do ściagania podatków i właścicielom nie zależało na podawaniu wartości zgodnych $z$ rzeczywistością. Trudno jednak ocenić, w jakim stopniu to rzeczywistość mijała się $z$ informacjami umieszczonymi przez spisujących. Na pewno niezależnym od tego zjawiskiem były podziały majątków i zmniejszenie się grupy najbardziej zamożnych przedstawicieli szlachty w powiecie orłowskim. Nie można tego zauważyć, biorąc pod uwage liczbę wsi w majątkach. Inaczej rzecz się ma, gdy dokona się analizy liczby dymów. Najlepszym przykładem ilustrujacym to zjawisko były losy największej majętności, należącej do wojewody łęczyckiego S. Dzierzbickiego. W 1790 r. w rękach wdowy po nim była tylko połowa dymów, jakie posiadał jej mąż 15 lat wcześniej. To zjawisko przedstawia tabela 2, gdzie w 1775 r. było 26 majątków, liczących od sześciu do 10 dymów, a w 1790 r. jedynie 12. Prawdopodobnie część $z$ nich weszła w skład większych majętności, co odzwierciedlają dane dotyczącej większej liczby dymów. Jednak największy wzrost odnotowuje się w najniższej grupie, gdzie $z$ pewnością znalazły się części tworzące kiedyś większe majętności. Poza tym nastapił niewielki wzrost majątków liczących pięć dymów. Innym zjawiskiem było kumulowanie części osad w rękach jednego właściciela. Zbyt krótki okres nie pozwala ocenić, na ile ta tendencja okazała się trwała. Proces ten nie zwiększył liczby wsi, które miały jednego właściciela. Za sukces można uznać zjawisko przejęcia jednej, dwu lub więcej części, co stwarzało w przyszłości możliwość scalenia całości. Jednak nie było żadnej gwarancji, że do tego dojdzie, natomiast zawsze istniała obawa kolejnych podziałów po śmierci właściciela.

\section{Bibliografia}

\section{$\dot{\mathbf{Z}}_{\text {RÓDEA ARChIWALNE }}$}

Archiwum Główne Akt Dawnych

Księgi grodzkie łęczyckie, varia nr 7, 11. 


\section{WYDAWNICTWA ŹRÓDEOWE}

Volumina legum, t. VIII, Petersburg 1860.

\section{OpRacowania}

Atlas historyczny Polski, t. V (Województwo sieradzkie i województwo łęczyckie w drugiej połowie XVI wieku), cz. 2, red. H. Rutkowski, Warszawa 1998.

Drozdowski M., Podstawy finansowe działalności państwowej w Polsce 1764 1793. Działalność budżetowa Sejmu Rzeczypospolitej w czasach panowania Stanisława Augusta Poniatowskiego, Warszawa-Poznań 1975.

Filipczak-Kocur A., Skarbowość Rzeczypospolitej 1587-1648. Projekty, ustawy, realizacja, Warszawa 2006.

Kajzer L., Studia nad świeckim budownictwem obronnym województwa łęczyckiego w XIII-XVII wieku, „Acta Universitatis Lodziensis”, Folia Archaeologica 1980, t. I, 1980, s. 3-414.

Korzon T., Wewnętrzne dzieje Polski za Stanisława Augusta (1764-1794), t. III, Kraków-Warszawa 1897.

Nycz M., Geneza reform skarbowych sejmu niemego. Studium z dziejów skarbowowojskowych z lat 1697-1717, Poznań 1938.

Romaniuk P.P., Sołłohub (Ursyn Dowojna Sołłohub) Józef Antoni h. Prawdzic (1709-1781), kasztelan żmudzki i witebski, wojewoda witebski, [w:] Polski słownik biograficzny, t. XL, Warszawa-Kraków 2000-2001, s. 319-323.

Romaniuk P.P., Sołłohub (Ursyn Dowojna Sołłohub) Jan Michał h. Prawdzic (1747-1812?), starosta sannicki, generał w służbie rosyjskiej, [w:] Polski słownik biograficzny, t. XL, Warszawa-Kraków 2000-2001, s. 315-318.

Sobczak T., Zmiany $w$ stanie posiadania dóbr ziemskich $w$ województwie łęczyckim od XVI do XVIII wieku, „Roczniki Dziejów Społecznych i Gospodarczych” 1955, t. XVII, s. 163-193.

Szczygielski W., Struktura społeczno-własnościowa szlachty łęczyckiej $w$ poczatkach drugiej połowy XVII w., „Acta Universitatis Lodziensis”, „Zeszyty Naukowe Uniwersytetu Łódzkiego", Nauki Humanistyczno-Społeczne, Folia Historica, Seria I, „Feudalizm”, 1979, z. 57, s. 151-166.

Wajs H., Materiały skarbowe $w$ aktach ziemskich i grodzkich w AGAD (na przykładzie akt sieradzkich i łęczyckich), „Miscellanea Historico-Archivistica” 1999, t. X, s. $76-115$.

Wierzbowski T., Akty ziemskie i grodzkie XIV-XVIII w. województw wielkopolskich [w:] Monumenta iuris, t. VI, Warszawa 1917, s. 4-178.

Zajączkowski S.M., Powiat orłowski do lat siedemdziesiatych XVI wieku. Studia $z$ dziejów osadnictwa struktury własnościowej i stosunków kościelnych, Łódź 1996.

Zajaczkowski S.M., Sieć parafialna na obszarze przedrozbiorowego powiatu orłowskiego do końca XVI wieku, Kutno 2001.

Zajączkowski S.M., Uwagi o przeszłości Orłowa do lat siedemdziesiątych XVI wieku, „Rocznik Łódzki” 1996, t. XLIII, s. 53-72. 
Żerek-Kleszcz H., Majętność oporowska i Sołłohubowie w XVIII wieku, [w:] Oporów. Stan badań. Materiały z sesji naukowej zorganizowanej z okazji 50 rocznicy Muzeum w Oporowie 22 listopada 1999 roku, Oporów 2000, s. 135-148.

Michą Kobierecki

\section{Noble estates and their owners in the Orłow county in the second half of the $18^{\text {th }}$ century}

$\mathrm{T}$

he Orłów county, being one of the smallest in the Polish-Lithuanian Commonwealth, was a part of the Łęczyca voivodship. The towns, villages and other real estate in this county belonged exclusively to the nobility and to the Catholic Church. The contemporary historians investigating the ownership of these properties in the $16^{\text {th }}$ and $17^{\text {th }}$ centuries unambiguously determined that the accumulation of properties and creation of large estates made up of a dozen or more villages did not occur in the said county. The owners of noble estates were not too wealthy, neither in the country nor in the voivodship. The situation did not change in the next century, as confirmed by the study into the records of the chimney tax in 1775 and the head tax in 1790, which covered the entire Łęczyca voivodship. At the time, the most affluent was the voivode of Łęczyca, Szymon Dzierzbicki, being in possession of the town of Bielawa and eight villages, as well as the voivode of Vitebsk, Józef Sołłohub, the owner of Żychlin, six full villages and a part. In 1790, the largest property, including six villages, belonged to the general of the Russian army, Jan Sołłohub. It confirms that no noble estate that would be composed of over ten towns existed in the Orłów county. The area was dominated by small estates, consisting of one or two villages, or their parts, which mainly belonged to the less affluent nobility. In some cases, a village was owned by two or three noblemen, but sometimes even by thirteen. Over the next 15 years, the situation has not changed significantly since the process of property consolidation did not take place. The group of landowners did not grow smaller, and the analysis of the number of chimneys in the villages of the Orłow county in 1790 indicated that a considerable part of the Orłow nobility was working the land and was also tax exempt for having small estate.

Keywords: Polish nobility in the $18^{\text {th }}$ century, Orłów county, noble estate. 